\title{
Lipid-Protein Interactions in Langmuir Monolayers under Dynamically Varied Conditions
}

\section{Martyna Krajewska, Katarzyna Dopierała*, Krystyna Prochaska}

Institute of Chemical Technology and Engineering, Poznan University of Technology, Berdychowo 4, 60-965 Poznań, Poland

*corresponding author, e-mail: katarzyna.dopierala@put.poznan.pl

\section{Supplementary material}

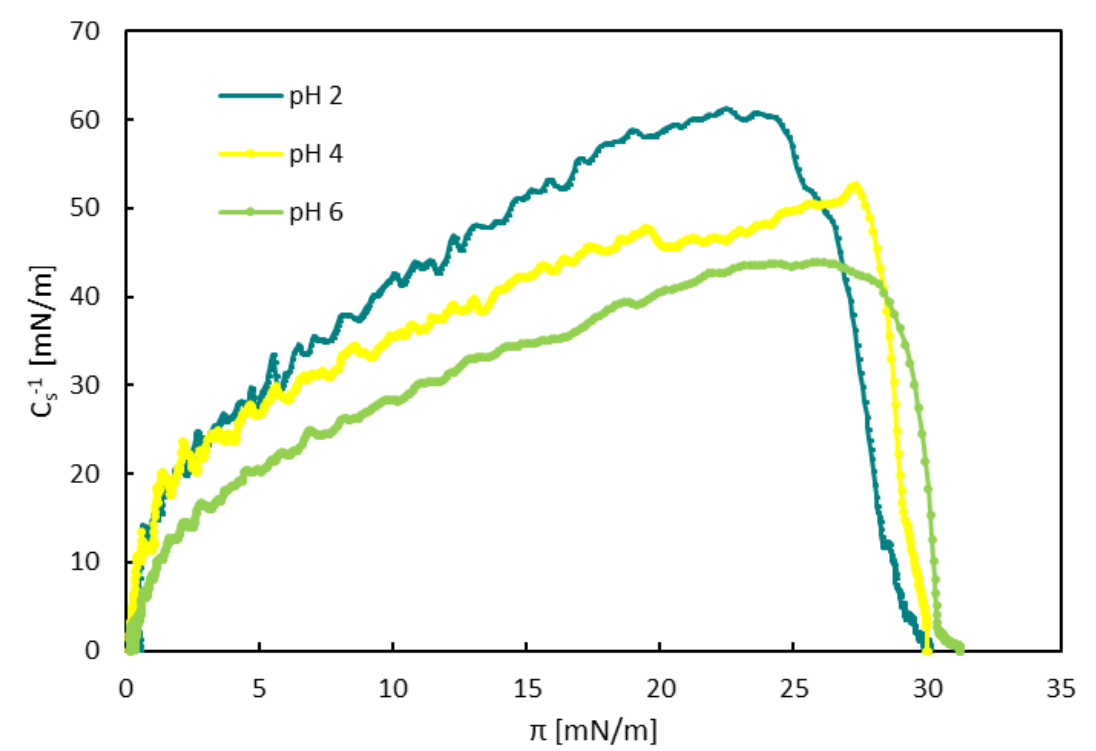

Figure S1. Compression modulus $\left(\mathrm{C}_{\mathrm{s}}^{-1}\right)$ as a function of surface pressure $(\pi)$ for oleic acid monolayers on different subphase $\mathrm{pH}$

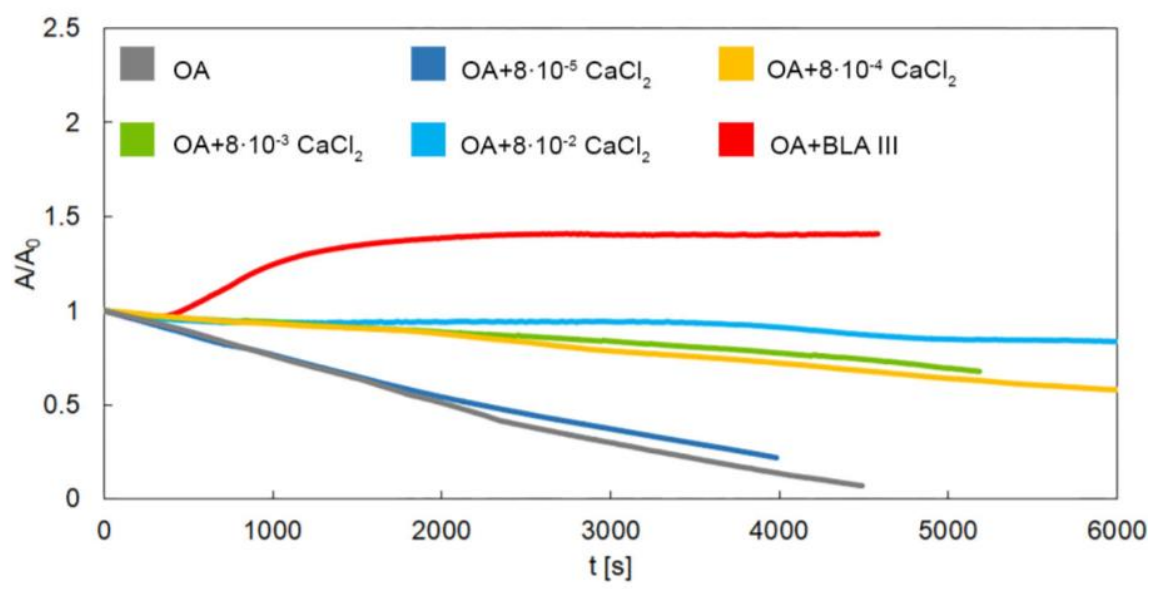

Figure S2. Relative area changes during relaxation/penetration experiments after subphase exchange 


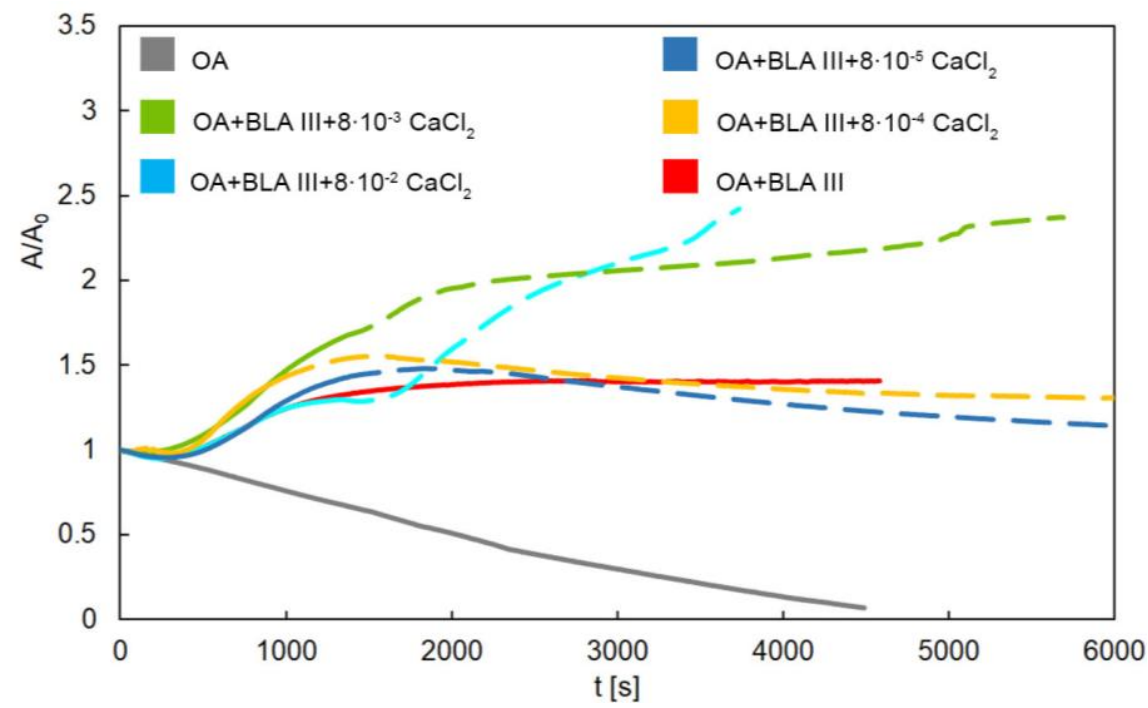

Figure S 3. Relative area changes during relaxation/penetration experiments for single (solid lines) and double subphase exchange (dashed lines) 